African Crop Science Journal by African Crop Science Society is licensed under a Creative Commons Attribution 3.0 Uganda License. Based on a work at www.ajol.info/ and www.bioline.org.br/cs DOI: https://dx.doi.org/10.4314/acsj.v27i4.6

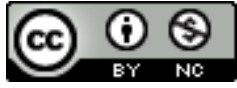

\title{
ENHANCING PRODUCTIVITY OF FARMER-SAVED SEED YAM IN GHANA: POSITIVE SELECTION AND NEEM LEAF POWDER FACTORS
}

\author{
K. OSEI, S. A. ENNIN, B. AIGHEWI ${ }^{1}$, A.K. AIDOO, J.N.L. LAMPTEY, M.B. MOCHIAH, \\ D. AIHEBHORIA ${ }^{1}$, J. ADOMAKO, Z. APPIAH-KUBI, G.O. MENSAH, B.O. ASANTE, \\ J.O. ADU and A.S. OSUMAN
}

CSIR - Crops Research Institute, P. O. Box 3785, Kumasi, Ghana

${ }^{1}$ International Institute of Tropical Agriculture (IITA), PMB 82, Abuja, Nigeria

Corresponding author: oseikingsley4@gmail.com

(Received 10 June 2019; accepted 26 November 2019)

\begin{abstract}
Recycling of diseased and pests infested seed yam (Dioscorea spp.) has resulted in drastic yield reductions in yam production. The objective of this study was to determine the effect of positive selection on the quality of farmer-saved seed yam and also evaluate the effect of neem leaf powder in managing plant parasitic nematodes damage to yam. Two farming systems namely; Positive selection (PS) and Farmer practice (FP) and two soil amendment regimes; neem leaf powder at $20 \mathrm{~g} \mathrm{stand}^{-1}$ (NA20) and no neem amendment (NA0) were tested on one variety of yam (Dente). A $2 \times 2 \times 1$ factorial study, mounted on a randomised complete block design in a split plot arrangement was conducted in four replications. Positive selection occupied main plots; while Farmer practice occupied sub-plots. The study was conducted in eight communities located in two municipalities of Ghana, during 20152017. Parameters evaluated included Yam Mosaic Virus incidence and severity, incidence and severity of nematode cracks and galling on yam tubers, plant establishment and yield of yam. It was observed that Yam Mosaic Virus (YMV) disease incidence decreased from 38\% in 2016 to 31\% in 2017 in PS plots as a result of using virus-free planting materials. However, in FP plots, it increased from 67\% in 2016 to $72 \%$ in 2017 . Neem leaf powder amendment resulted in significantly $(\mathrm{P}<0.05)$ low tuber galling $(7 \%)$ compared with $40 \%$ in unamended plots. Similarly, PS plots yielded $7.7 \mathrm{t} \mathrm{ha}^{-1}$ compared to $5.9 \mathrm{t} \mathrm{ha}^{-1}$ in FP fields. In conclusion, Positive selection out-yielded FP by $30.5 \%$; while PS-neem leaf powder interaction resulted in $38.5 \%$ over and above FP without neem amendment.
\end{abstract}

Key Words: Dioscorea spp., parasitic nematodes, yam mosaic

\section{RÉSUMÉ}

Le recyclage des semences d'igname (Dioscorea spp.) contaminées par des maladies et des parasites a entrainé une réduction drastique du rendement de la production d'igname. L'objectif de cette étude était de déterminer l'effet de la sélection positive sur la qualité des semences d'igname conservées par les agriculteurs et également d'évaluer l'effet de la poudre de feuilles de neem dans la gestion des 
dommages causés par les nématodes parasites des plantes. Deux systèmes agricoles à savoir; Sélection positive (PS) et pratique paysanne (PF) et deux régimes d'amendement du sol; De la poudre de feuille de neem à $20 \mathrm{~g}$ du stand-1 (NA20) et aucun amendement de neem (NA0) ont été testés sur une variété d'igname (Dente). Une étude factorielle de 2 × 2 × 1, montée sur une dispositif en blocs aléatoires complets dans un arrangement en parcelles divisées, a été menée en quatre répétitions. Sélection positive occupée parcelles principales; tandis que la pratique paysanne occupait des sous-parcelles. L'étude a été menée dans huit communautés situées dans deux municipalités du Ghana en 2015-2017. Les paramètres évalués comprenaient l'incidence et la gravité du virus de la mosaïque de l'igname, l'incidence et la gravité des fissures de nématode et le grippage des tubercules de l'igname, l'établissement de la plante et le rendement de l'igname. Il a été observé que l'incidence de la maladie causée par le virus de la mosaïque à l'igname (YMV) avait diminué de 38\% en 2016 à $31 \%$ en 2017 dans les parcelles PS grâce à l'utilisation de matériel de plantation dépourvu de virus. Cependant, dans les parcelles de PF, il est passé de $67 \%$ en 2016 à $72 \%$ en 2017. L'amendement de poudre de feuille de Neem a entraîné une réduction significative du galles des tubercules $(\mathrm{P}<0,05)(7 \%)$ par rapport à $40 \%$ dans les parcelles non modifiées. De même, les parcelles de PS ont produit 7,7 t ha ${ }^{-1}$, contre 5,9 $\mathrm{t} \mathrm{ha}^{-1}$ dans les champs de PF. En conclusion, la sélection positive a eu un rendement supérieur de $30,5 \%$ à celui de la PF; tandis que l'interaction de la poudre de feuille PS-neem a eu pour résultat 38,5\% de plus que FP sans amendement de neem

Mots Clés: Dioscorea spp., nématodes parasitaires, mosaïque d'igname

\section{INTRODUCTION}

Yam (Dioscorea spp.) is an important food security crop in West Africa, where more than $90 \%$ of the world production is cultivated (FAO, 2009). Besides its importance as food source, yam also plays a significant role in the socio-cultural lives of people in West Africa (Osunde and Orhevba, 2009), by providing cash income for a wide range of smallholders, including many women as processors and traders (Asiedu, 2003). More importantly, yam tubers have organoleptic qualities which make them the preferred carbohydrate staple and can contribute up to 350 dietary calories per person each day (Asiedu et al., 2001).

Tubers of D. hamiltonii are used as "body refrigerant" during summer and are also used to treat diarrhoea (Duta, 2015). Therefore, improving yam productivity can increase food production and farmers' income in the producing areas, particularly in West Africa as propounded by Hgaza et al. (2010).

The average yield of yam in most production areas in West Africa is $10.2 \mathrm{t} \mathrm{ha}^{-1}$ (FAO, 2011); while the potential yield onstation is approximately $21 \mathrm{t} \mathrm{ha}^{-1}\left(\mathrm{O}^{\prime}\right.$ Sullivan and Ernest, 2008). The poor yield levels in West Africa is the result of several constraints, including lack of quality planting material, low soil fertility, pest and disease problems.

In the past, significant edaphic investigations (Diby, 2005; O'Sullivan and Ernest, 2008; Ettien et al., 2009) led to recommendations of fertiliser strategy in yam production. However, limited attention has since been paid to addressing disease and pest occurrences in yam production systems, especially in Ghana where virus infection and plant-parasitic nematodes damage are major constraints to yam tuber quality reduction, yield losses in the field and storage.

The major nematode pests associated with yam production include the yam nematode, Scutellonema bradys, and root-knot nematode, Meloidogyne spp., which are field and postharvest pests (Agbaje et al., 2003; Adegbite et al., 2005). Recycling of diseases and pests infested seed yam has resulted in drastic yield reduction in yam production

An intervention (Positive selection) introduced by the Community Action in Improving Farmer-Saved Seed Yam (CAYSeed) project in Ghana was to reverse the 
decline in the productivity of yam. Positive selection (PS) strategy is the identification, tagging, monitoring and harvesting of tubers from symptomless mother plants for seed production (Kakuhenzire et al., 2013). The objective of this study, therefore, was to determine the effect of positive selection on the quality of farmer-saved seed yam and also evaluate the effect of neem leaf powder application in managing plant parasitic nematodes damage to yam.

\section{MATERIALS AND METHODS}

Participatory research in farmers' fields were setup in eight yam-producing communities, four communities each in Ejura-Sekyedumasi and Atebubu-Amantin districts of Ashanti and Brong Ahafo regions of Ghana, respectively. Treatments were 2 farming systems; Positive Selection (PS) and Farmer Practice (FP); and 2 soil treatment options; neem leaf powder amendment $20 \mathrm{~g} \mathrm{stand}^{-1}$, and no neem application. These were tested on one local variety of yam "Dente", a variety preferred and cultivated by farmers in the study areas.

The study was conducted during 20152017. Each district had two PS and two FP communities, with each community representing a replication (Table 1). In each community, thirty male and females farmers were randomly selected for the study.

Experimental design. The experimental design employed for this study was a $2 \times 2 \times 1$ factorial mounted on a split plot treatment arrangement and replicated four times. Two farming systems; Positive selection (using disease and virus-free seed for planting) and Farmer practice (seed obtained from milking ware yam) occupied main plots, while two amendment options; $20 \mathrm{~g}$ neem leaf powder and no neem application occupied sub-plots. PS and FP demonstration plots were established for the target communities on 20 x $20 \mathrm{~m}$ plot size. The plots were stumped, cleared and ridged at a spacing of $100 \mathrm{~cm}$ between rows. Spacing between plants on a row was $30 \mathrm{~cm}$.

Positive selection (PS) was done in farmers' fields in 2015 in PS designated communities and healthy seed yams were selected, stored and used for the work in 2016 when communities designated as Farmer Practice joined the studies. A local variety Dente, was used for the studies from 2016 to 2017. In FP communities, farmers selected seed produced from milking their yam fields and used for the work.

TABLE 1. Treatments deployed and site locations of selected communities in Ghana

\begin{tabular}{llccc}
\hline Treatments & Communities & \multicolumn{3}{c}{ GPS Coordinates } \\
\cline { 3 - 5 } & & Latitude & Longitude & Altitude $(\mathrm{m})$ \\
\hline \multirow{2}{*}{ Positive Selection } & Mem & 7.685086944 & -0.973756111 & 164.80 \\
& Abour & 7.598345833 & -1.107137778 & 199.27 \\
& Bissiw & 7.328587778 & -1.294143333 & 202.31 \\
& Nyinase & 7.5872125 & -1.355644722 & 176.76 \\
& & & & 175.92 \\
Farmer Practice & Watro & 7.613202778 & -0.966043611 & 184.72 \\
& Asanteboa & 7.643482222 & -1.088851389 & 195.55 \\
& Kramokrom & 7.326456389 & -1.290083889 & 241.82 \\
& Mesuo & 7.5375975 & -1.303635278 & \\
\hline
\end{tabular}


Seed yam tubers were cut into minisetts of $30 \mathrm{~g}$ each using sharp, sterilised knives. Minisetts were then treated with a fungicide, $100 \mathrm{~g}$ ethylene bisdithiocarbamate (Mancozeb) and an insecticide, $40 \mathrm{ml}$ lambda cyhalothrin in 10 litres of water was prepared and minisetts submerged in it with the help of a net, for five minutes. The treated minisetts were then allowed to air dry under shade for at least 60 minutes, before planting on ridges.

Neem leaf powder (already prepared by milling) was applied at a rate of $20 \mathrm{~g}$ per stand, at planting. Control plots were not treated with neem leaf powder. During planting, cut surfaces of minisetts were directed upwards in the planting hole $(8 \times 8 \times 8) \mathrm{cm}^{3}$ to prevent rotting. The $20 \mathrm{~g}$ neem powder was placed at the base of the planting hole, about $100 \mathrm{ml}$ soil was used to cover it before placing the minisett and properly covered with about 300 $\mathrm{ml}$ soil.

Plant establishment counts were conducted at 30,60 and 90 days after planting to evaluate the number of minisetts that sprouted and harvested per treatment. Field sanitation, especially weed management was ensured right from the beginning. Trellis staking (using bamboo poles and thick ropes) were employed to reduce the number stakes in the research plots.

For PS plots, plants which showed no morphological symptoms of yam mosaic virus were identified with tags, using paper ribbons placed at the basal part of the vines (Fig. 1). This activity was repeated two months after the first one. Plants which were considered morphologically clean and were tagged, but showed mosaic symptoms two months after the first exercise were discarded by removing the tags they received during the first tagging exercise. Incidence and severity of yam mosaic virus disease were documented from the community research plots. For this purpose, 30 plants were randomly assessed diagonally in all treatments, and the counts expressed as percentages. A scale of 1-5 was used to visually assess the extent of mosaic symptom on the yam leaves where $1=$ no symptom expression and $5=$ severely affected (Sseruwagi et al., 2004).

Seed yams were harvested in December, 2016 and December, 2017. Harvesting was done using hand hoes and cutlasses. Weight measurements and sorting of seed yams were categorised as; Ware yam ( $>1 \mathrm{~kg})$, Seed A (999$500 \mathrm{~g})$, Seed B (499-100 g) and Micro-tubers

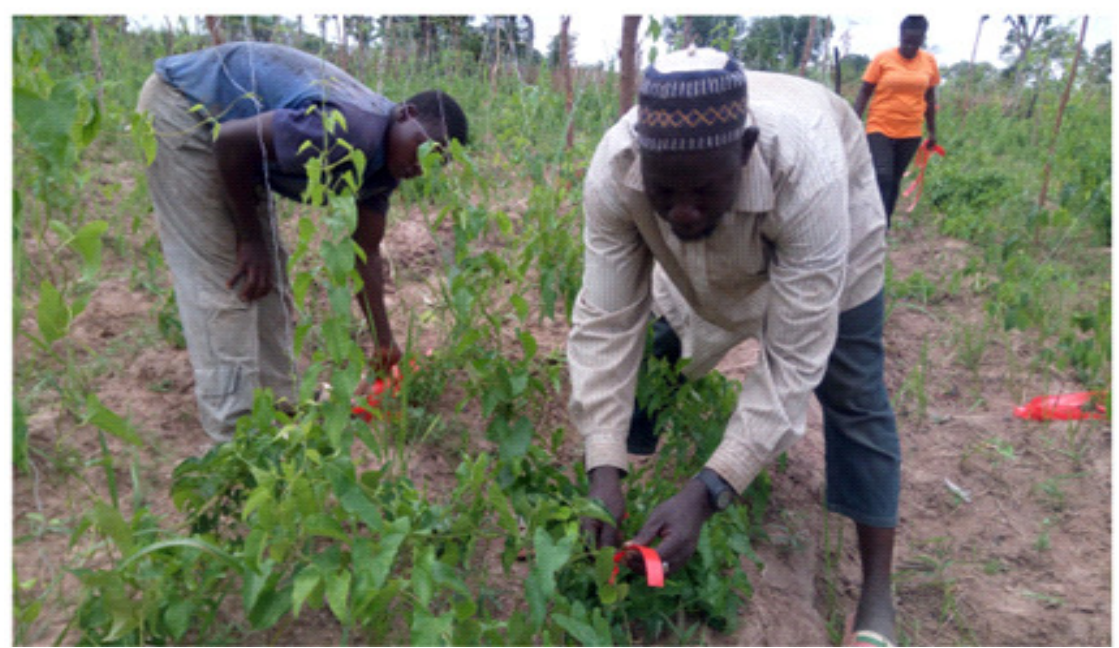

Figure 1. Farmers practicing in positive selection on the field in Ghana. 
$(<100 \mathrm{~g})$. Harvested tubers showing symptoms of cracks were assessed for incidence and severity; while galls were assessed in terms of incidence and severity (index) (on a scale of 1-5) according to Sseruwagi et al. (2004). For PS plots, clean and healthy plants which were tagged were harvested and assessed separately from yam mosaic infected seed yams (untagged).

Data collected for the two-year period were pooled together and subjected to ANOVA using SAS version 9.4 statistical tool. Index based data were square root transformed $(\sqrt{ }(\mathrm{x}+$ $0.5)$ before analysis. Means were separated using the Fisher's Least Significant Difference test at $(\mathrm{P} \leq 0.05)$.

\section{RESULTS}

Morphological observations and assessment of yam plants revealed the occurrences of yam mosaic attacks (Fig. 2). With respect to virus infection, morphological symptoms ranging from mosaic, leaf mottling, vein banding, vein clearing, to leaf chlorosis were common field symptoms observed on both young and matured yam leaves.
Yam mosaic disease incidence decreased significantly $(\mathrm{P} \leq 0.05)$ from $38 \%$ in 2016 to $31 \%$ in 2017 in PS plots. In contrast, in FP plots, it increased from $67 \%$ in 2016 to $72 \%$ in 2017 (Fig. 3).

Neem leaf powder amendment at $20 \mathrm{~g}$ stand $^{-1}$ reduced the incidence and severity of tuber attack by nematodes resulting in cracks compared to plots without neem leaf powder amendment. Roots on yam tuber commonly referred to as "crazy roots", and tuber galling due to plant parasitic nematodes attack were prevalent in no neem amended (control) plots compared to neem leaf powder amended plots (Fig. 4).

Tubers harvested from no neem amended Farmer practice plots (FPNA0) recorded tuber galling incidence of forty percent, with a corresponding gall index of 2.7. However, in Farmer practice plots amended with neem leaf powder (FPNA20), significantly low galling incidence of $7 \%$ and an index of 1.4 was recorded. Similarly, tuber crack incidence and severity were significantly high $(24.9 \%)$ and 2.5 in no neem amended FP plots compared to $6.1 \%$ incidence and 1.5 severity recorded on amended plots, respectively (Table 2). In

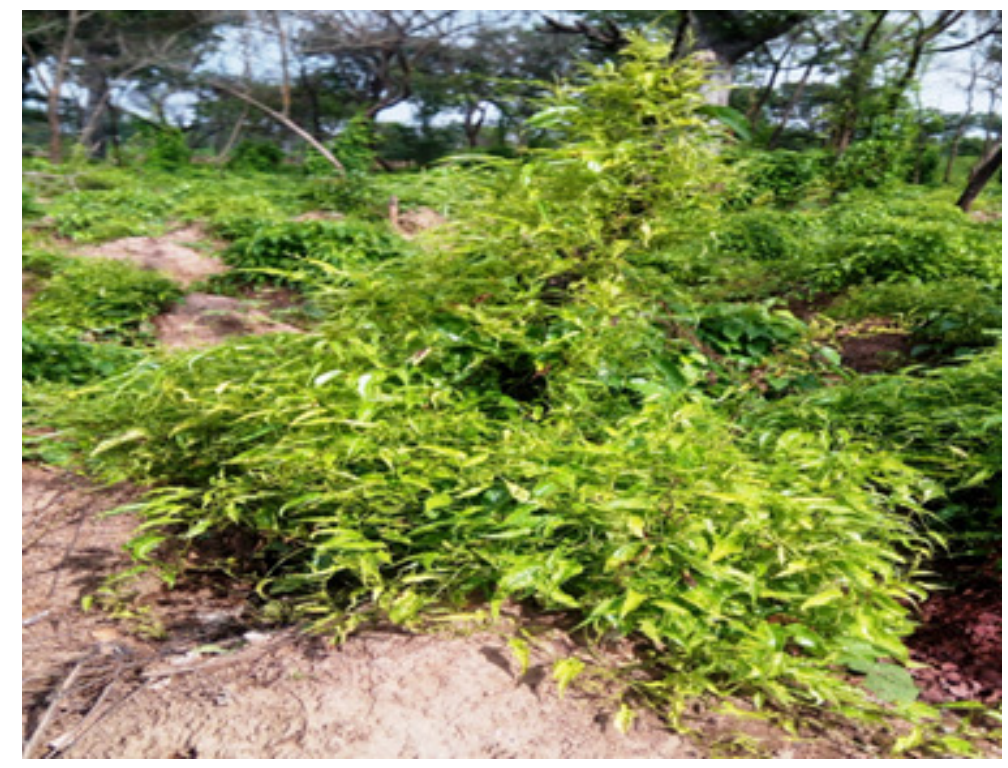

Figure 2. Field symptoms of yam mosaic disease. 


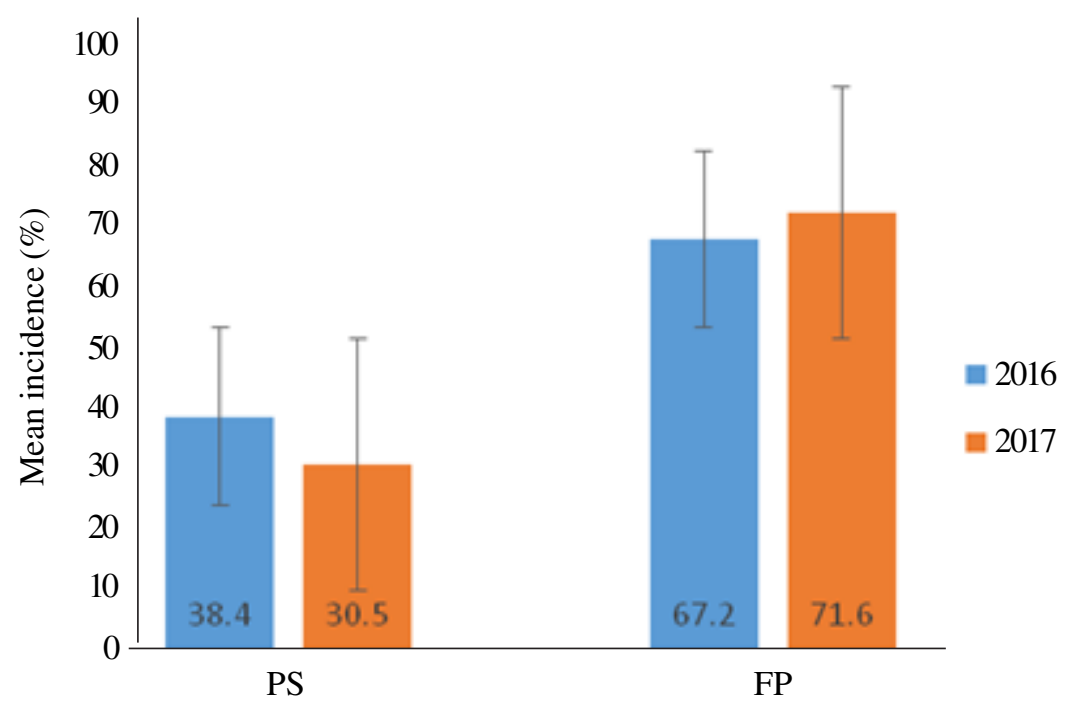

Figure 3. Yam mosiac incidence (\%) in Positive selection (PS) and Farmer practice (FP) plots in 2016/2017 in yam growing communities in Ghana.

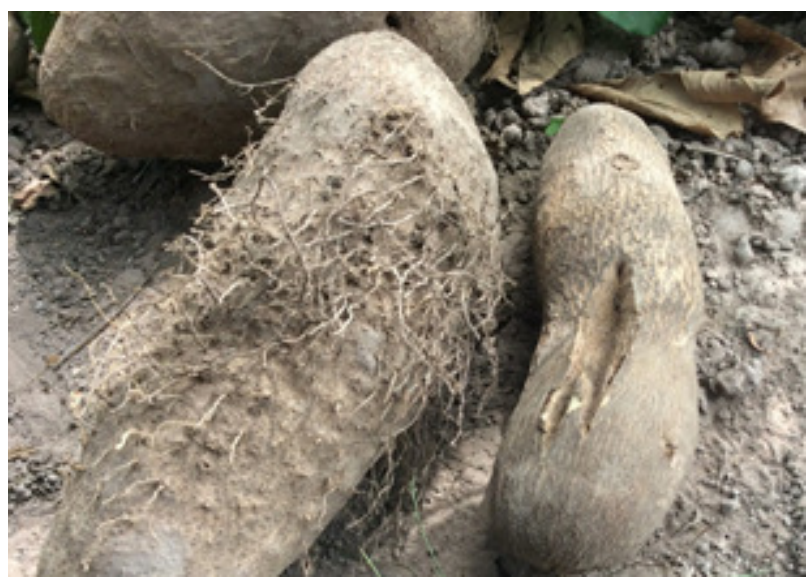

Figure 4. Crazy roots and crack on tubers caused by nematodes.

PS, no neem amended plots (PSNA0), significantly high $(22 \%)$ of seeds were found with galls with corresponding gall index of 2.0. Tuber cracks incidence and severity were 15.1 and $1.9 \%$, respectively (Table 2 ). However, PS interacted positively with $20 \mathrm{~g}$ neem leaf powder (PSNA20) to significantly reduce galling incidence to $4.2 \%$ and galling index to 0.8 . Tuber cracks incidence and severity reduced to $5 \%$ and 1.2 , respectively. In terms of plant stand, a significantly high value (242) was recorded for PS plots compared with (209) in FP plots (Fig. 5).

There were significant differences $(\mathrm{P}<$ $0.05)$ in average yield of seed yam between PS and FP plots. It was observed that PS plots recorded an average yield of $7.7 \mathrm{t} \mathrm{ha}^{-1}$ as compared with $5.9 \mathrm{t} \mathrm{ha}^{-1}$ for FP plots. It was further observed that neem amended plots increased yield of seed yam. While FP without neem amendment recorded $5.9 \mathrm{t} \mathrm{ha}^{-1}$ of seed yam, neem amended FP recorded $7.1 \mathrm{t} \mathrm{ha}^{-1}$. 
TABLE 2. Effect of neem leave powder amendment " on incidence and severity of nematode infestation

\begin{tabular}{lcccc}
\hline Treatments & $\begin{array}{c}\text { Galling } \\
\text { incidence }(\%)\end{array}$ & $\begin{array}{c}\dagger \text { Galling } \\
\text { index }(0-5)\end{array}$ & $\begin{array}{c}\text { Tuber crack } \\
\text { incidence }(\%)\end{array}$ & $\begin{array}{c}\text { Tuber crack } \\
\text { severity (1-5) }\end{array}$ \\
\hline FPNA0 & 40.0 & 2.7 & 24.9 & 2.5 \\
FPNA20 & 6.8 & 1.4 & 6.1 & 1.5 \\
PSNA0 & 22.0 & 2.0 & 15.1 & 1.9 \\
PSNA20 & 4.2 & 0.8 & 5.0 & 1.2 \\
LSD (P $\leq 0.05)$ & 12.4 & 0.4 & 7.3 & 0.2
\end{tabular}

$\dagger$ Galling rated on a scale of $(0-5) ; 0=0 \%, 1=1-25 \%, 2=26-50 \%, 3=51-75 \%, 4=76-99 \%$ and $5=100 \%$ of roots galled

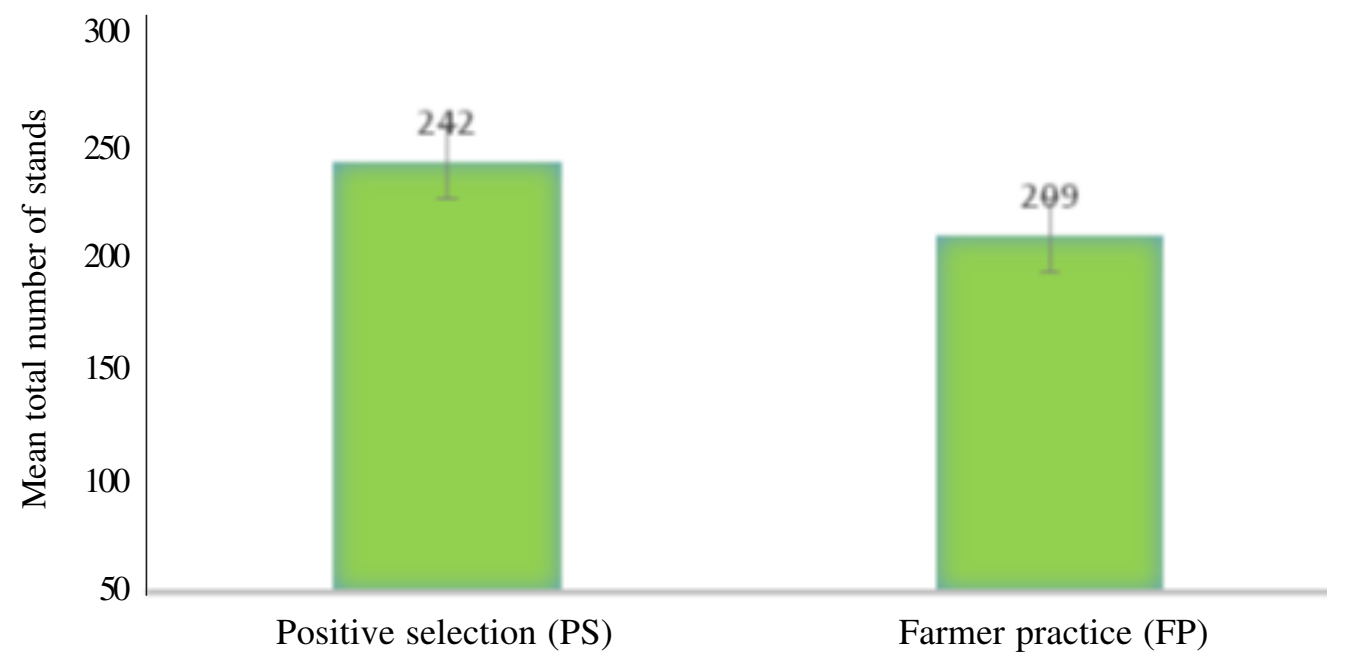

Figure 5. Effect of Positive selection (PS) on total number of yam stand at harvest $\left(120 \mathrm{~m}^{2}\right)$.

Similarly, unamended PS plots produced $7.7 \mathrm{t}$ $\mathrm{ha}^{-1}$ whilst neem amended PS plots produced $9.6 \mathrm{t} \mathrm{ha}^{-1}$ (Table 3).

\section{DISCUSSION}

The higher yam mosaic disease incidence observed in FP plots compared to PS plots (Fig. 3) can be attributed to the accumulation of viruses in farmer saved-seed over multiple cycles of vegetative propagation, the possible exchange of yam materials between farmers and from market sources. This result agrees
TABLE 3. Treatment effects on yield of seed yam

\begin{tabular}{ll}
\hline Treatments & Yield $\left(\mathrm{t} \mathrm{ha}^{-1}\right)$ \\
\hline PS +NA0 & $7.7 \mathrm{~b}$ \\
PS +NA20 & $9.6 \mathrm{c}$ \\
FP +NA0 & $5.9 \mathrm{a}$ \\
FP+NA20 & $7.1 \mathrm{~b}$ \\
LSD $(\mathrm{P} \leq 0.05)$ & 0.8
\end{tabular}

Means followed by different letters differ significantly by the Fisher's Least Significant Difference test at 0.05 probability 
with observations made by Aihebhoria et al. (2017) that farmer saved seed yam harbor disease pathogens.

Galling incidence and index were greater in FP seeds than with PS seeds. PS reduced galling incidence and index by 81.8 and $35 \%$, respectively (Table 2). The benefit of neem leaf powder amendment in reducing nematode infestation was demonstrated where FPNA20 seeds reduced galling incidence by $488 \%$ and galling index by $93 \%$ compared with FPNA0 seeds.

Similarly, PSNA20 seeds reduced galling incidence and index by 424 and $150 \%$, respectively, compared with PSNA0 seeds.

A similar trend was observed in tuber cracks incidence and severity. Compared with FP tubers, PS reduced tuber cracks and severity by 65 and $32 \%$, respectively; while PS combined with neem leaf powder amendment to reduce tuber cracks incidence and severity by 398 and $90 \%$, respectively.

The continuous keeping of infected planting materials in the hands of farmers for cultivation according to Njukeng et al. (2014) is due to the limited awareness about the potentials of positive selection in reducing viral and disease load in yam. Positive selection in yam production helps to select healthy looking materials for propagation, and also serves as parent materials for production of clean seeds. Planting disease-free seed yams reduces disease problems and this method has successfully been used to produce quality and disease free seed potato (Struik and Wiersema, 1999; Kakuhenzire et al., 2013).

Apart from reduction in incidence of mosaic disease, yields of seed yam significantly increased in PS compared to FP options. This agrees with findings of Aihebhoria et al. (2017) who worked on the response of white yam tuber portions to Positive Selection for quality seed yam production in Nigeria and found out that in addition to reductions in YMV incidence and severity, fresh tuber weight was significantly higher than control plots. In their study, the authors found out that PS fields recorded a tuber yield of $6.03 \mathrm{tha}^{-1}$ compared with $4.99 \mathrm{t} \mathrm{ha}^{-1}$ for FP plots. Similarly, Gildemacher et al. (2007) reported of 54\% yield increase in potato due to PS.

In addition to yield enhancing potential, PS ensures higher sprouting percentage. The total number of plants harvested from PS plots was 16\% more than FP plots (Fig. 5). The increased yields observed in PS plots suggest that seed yam productivity can be increased by simple selection of healthy plants. Again, Gildemacher et al. (2011) observed that PS plots recorded an average yield of $14.2 \mathrm{t} \mathrm{ha}^{-1}$, which was significantly higher than the $11.8 \mathrm{t} \mathrm{ha}^{-1}$ for farmer seed selection plots.

The observed increment in yield from PS materials could be due to the fact that healthy plants produce optimum assimilates which are translocated to the root and stored in tubers as starch. In the current study, PS fields outyielded FP fields by $30.5 \%$. Where PS fields were amended with neem leaf powder, the interaction resulted in appreciated yields of $38.5 \%$ over and above FP without neem amendment

Nematodes have been reported to reduce quality of yam tubers (Imafidor and Mukoro, 2016). Apart from reducing yield, their activities provide avenue for other pathogenic microorganisms causing diseases on seed yams. The application of neem to manage nematodes has been reported in several studies (Nazir et al., 2006; Osei et al., 2013; Kankam and Adomako, 2014). Individually, PS and neem amendment contributed to yield improvement and reduced the effect of virus and nematodes stress. This indicates the relevance of employing integrated approaches in managing biotic stresses to improve productivity of farmer-saved seeds. Combining low cost management technologies such as PS and neem leaf powder amendment has the advantage of increasing yield at minimum cost which is crucial to resource-poor smallholder farmers. The participation of farmers and simplicity in identifying, selecting and tagging healthy looking materials convincingly show 
that the PS technology can easily be adopted and substantially increase smallholder farmersaved seed yam productivity.

\section{ACKNOWLEDGEMENT}

Authors acknowledge technical assistance of John Sackey-Asante, Micah Offei Apraku and Augustine Agyekum of CSIR-Crops Research Institute and the staff of MoFA in the EjuraSekyedumasi and Atebubu-Amantin Municipalities. This research was supported by Bill and Melinda Gates Foundation Contract ID OPP1114092 under the CAY-Seed project.

\section{REFERENCES}

Adegbite, A.A., Adesiyan, S.O., Agbaje, G.O. and Omoloye, A.A. 2005. Host suitability of crops under yam intercrop to root-knot nematode (Meloidogyne incognita Race 2) in south-western Nigeria. Journal of Agriculture and Rural Development in Tropics and Subtropics 106 (2): 113-118.

Agbaje, G.O., Adegbite, A.A. and Akinlosotu, T.A. 2003. Performance of new hybrid yam (Dioscorea rotundata Poir) varieties in the forest zone of Nigeria. Tropicultura 21(3): 149-152.

Aihebhoria, D.O., Aighewi, B. and Balogun, M. 2017. The response of white yam (Dioscorea rotundata Poir) tuber portions to positive selection for quality seed yam production. Advances in Crop Science and Technology 5:294. doi:10.4172/2329. 8863.1000294.

Asiedu, R. 2003. Yams production in West Africa and collaborative research. Agronomie Africaine. Numero Special 4: 173-176.

Asiedu, R., Mignouna, H., d"A. Odu, B. and Hughes, J. 2001. Yam breeding. Presented at Plant Virology in Sub-Saharan Africa (PVSSA) Conference. International Institute of Tropical Agriculture (IITA), Nigeria. pp. 466-475.
Diby, L.N. 2005. Etude de l'elaboration du rendement chez deuxespècesd'igname (Dioscorea spp.). Thèse unique de Doctorat, Universite de Cocody, Abidjan 180 pp.

Dutta, B. 2015. Food and medicinal values of certain species of Dioscorea with special reference to Assam. Journal of Pharmacognosy and Phytochemistry 3: 1518.

Ettien, D.J.B., Kone, B., Kouadio, K.K.H., Kouadio, N.E., Yao-Kouame, A. and Girardin, O. 2009. Fertilisation minérale des ferralsols pour la production d'ignameen zone de Savane Guinéenne de l'Afrique de l'Ouest: cas des variétés d'igname traditionnelles surdystric ferralsols du Centre de la Côte d'Ivoire. Journal of Applied Biosciences 23:1394-1402.

FAO. 2011. FAOSTAT Crop production data. http://faostat.fao.org. (Accessed date: 25/ 02/2018).

FAO. 2009. FAOSTAT Crop production data. http://faostat.fao.org (Accessed date: 21/ 03/2018).

Gildemacher, P., Demo, P., Kinyae, P., Wakahiu, M., Nyongesa, M. and Zschocke, T. 2007. Select the best: Positive Selection to improve farm saved seed potatoes; Trainers' manual. Nairobi, Kenya: International Potato Centre. 103pp.

Gildemacher, P., Schulte-Geldermann, E., Borus, D., Demo, P. and Kinyae, P. 2011. Seed potato quality improvement through Positive Selection by smallholder farmers in Kenya. Potato Research 54: 253-266.

Hgaza, V.K., Diby, L.N., Assa, A. and Ake, S. 2010. How fertilization affects yam (Dioscorea alata L.) growth and tuber yield across the years. African Journal of Plant Science 4(3):053-060.

Imafidor, H.O. and Mukoro, U.L. 2016. Survey of plant parasitic nematodes associated with Dioscorea rotundata. International Journal of Advance Agricultural Research 4:16-19. 
Kakuhenzire, R.L., Emaga, B., Tibanyendra, D. and Schulte-Geldermann, E. 2013. Positive selection: A simple technique for improving seed potato quality and potato productivity among smallholder farmers. Acta Horticulturae 1007: 225-233.

Kankam, F. and Adomako, J. 2014. Efficacy of neem seed powder on root-knot nematodes (Meloidogyne spp.) infecting bambara groundnut (Vigna subterranean). Asian Journal of Agriculture and Food Sciences 02:166-170.

Nazir, J., Gowen, S.R., Inam-ul-Hag, M., Abdullah, K. and Shahina, F. 2006. Systemic and persistent effect of neem (Azadirachta indica) formulation against root-knot nematodes, Meloidogyne javanica and their storage life. Crop Protection 26: 911-916.

Njukeng, A.P., Azeteh, I.N. and Mbong, G.A. 2014. Survey of the incidence and distribution of two viruses infecting yam (Dioscorea spp.) in two agroecological zones of Cameroon. International Journal of Current Microbiology and Applied Sciences 3:1153-1166.
Osei, K., Otoo, E., Danso, Y., Adomako, J., Agyeman, A. and Asante, J.S. 2013. Organic soil amendments in nematode management in yam production. Nematropica 43(1):78-82.

O'Sullivan, J.N. and Ernest, J. 2008. Yam nutrition and soil fertility management in the Pacific. Australian Centre for International Agricultural Research, Brisbane. 143pp.

Osunde, Z.D. and Orhevba, B.A. 2009. Effects of storage conditions and storage period on nutritional and other qualities of stored yam (Dioscorea spp.) tubers. Africa Journal of Food, Agriculture, Nutrition. Development 9(2):678-690.

Sseruwagi, P., Sserubombwe, W.S., Legg, J.P., Nd-unguru, J. and Thresh, J.M. 2004. Methods of surveying the incidence and severity of cassava mosaic disease and whitefly vector populations in Africa: A review. Virus Research 100:129-142.

Struik, P.C. and Wiersema, S.G. 1999. Seed potato technology. Wageningen: Wageningen useful members of the Dioscorea. Longmans, London 40-135. 